\title{
Kesenian Penthul Tembem Di Kota Madiun (Studi Sejarah Dan Nilai Budaya)
}

\author{
Dita Yulianti, Novi Triana Habsari*, \\ Universitas PGRI Madiun \\ *Corresponding author`s e-mail: novitrianahabsari@unipma.ac.id
}

\begin{abstract}
Penthul Tembe art is the original art of Madiun City. But not a few people who do not know and understand the history and cultural values contained in it. For this reason, it is necessary to carry out research with the aim of describing and explaining the history of Penthul Tembem art and the cultural values contained in it. This research uses a descriptive approach which is carried out from March to June 2020. The data sources used are primary and secondary. Data were taken by interview, observation and documentation techniques. While the data analysis uses the interactive model of Miles and Huberman. From the research carried out, it can be explained that the history of Penthul Temb came from the journey of Ranggawarsita (Bagus Burhan Muda) son of Tumenggung Yasadipura from the Surakarta Palace who studied religion and state in Tegalsari. Until the end of the story, the meeting of two servants of Bagus Burhan in Madiun City Square who sing together wearing Penthul and Tembem masks. This event is called Penthul Tembem Art. The development of Penthul Tembem in Madiun City can be said to be lacking, due to the lack of attention from the government and society. The cultural values contained in the art of penthul Tembem can be seen in terms of its history and performances, which contain moral values, leadership values, religious values, aesthetic values and entertainment values. These values are values that can be applied in social life.
\end{abstract}

Keywords: Chubby Penthul; history; culture

Abstrak: Kesenian Penthul Tembemmerupakan kesenian asli Kota Madiun. Namun tidak sedikit warga masyarakat yang belum mengetahui dan memahami sejarah serta nilai-nilai budaya yang terkandung di dalamnya. Untuk itu perlu dilaksanakan penelitian dengan tujuan mendeskripsikan dan menjelaskan sejarah kesenian Penthul Tembemdan nilai budaya yang terkandung di dalamnya. Penelitian ini menggunakan pendekatan kualitatif deskriptif yang dilaksanakan mulai bulan Maret-Juni 2020. Sumber data yang digunakan bersifat primer dan sekunder. Data diambil dengan dengan teknik wawancara, observasi dan dokumentasi. Sedangkan analisis datanya menggunakan model interaktif Miles dan Huberman. Dari penelitian yang dilaksanakan dapat dijelaskan bahwa sejarah kesenian Penthul Tembemberasal dari perjalanan Ranggawarsita (Bagus Burhan muda) putra Tumenggung Yasadipura dari Keraton Surakarta yang menuntut ilmu agama dan kenegaraan di Tegalsari. Hingga pada akhir cerita adanya pertemuan dua abdi Bagus Burhan di Alun-Alun Kota Madiun yang ngamen bersama menggunakan topeng Penthul dan Tembem. Peristiwa inilah yang disebut dengan Kesenian Penthul Tembem. Perkembangan Penthul Tembemdi Kota Madiun bisa dikatakan kurang, dikarenakan kurang adanya perhatian Pemerintah dan masyarakat. Nilai-nilai budaya yang terkandung dalam kesenian penthul Tembemdapat dilihat dari segi kesejarahannya dan pementasannya yaitu terkandung nilai moral, nilai kepemimpinan, nilai religi, nilai estetika dan nilai hiburan. Nilai tersebut merupakan nilai yang dapat diterapkan dalam kehidupan bermasyarakat.

Kata kunci:Penthul Tembem; sejarah; budaya

\section{Pendahuluan}

Kesenian Negara Indonesia merupakan negara kepulauan yang terdiri dari berbagai suku bangsa. Kebudayaan Indonesia yang beraneka ragam seperti adat istiadat, kesenian serta kearifan lokal yang menjadi ciri khas masing-masing daerah. Banyaknya kebudayaan di Indonesia sehingga menjadi salah satu daya tarik tersendiri. Kebudayaan yang 
berkembang di Indonesia tidak hanyalah kebudayaan tradisional. Perpaduan budaya asing yang diakibatkan dari kemajuan teknologi juga menjadi hal yang sudah biasa di Indonesia. Salah satu unsur dari suatu kebudayaan yaitu kesenian. Kesenian merupakan segala sesuatu yang diciptakan dari diri sendiri serta menghasilkan suatu keindahan. Hal ini sesuai dengan pendapat Mulyadi (Sulistyo, 2005) mengatakan bahwa seni merupakan suatu hasil karya manusia yang berasal dari batinnya, serta disajikan secara indah sehingga dapat merangsang pengalaman untuk menghayatinya. Kesenian memiliki nilai-nilai yang tinggi serta perwujudannya berasal dari nilai nilai kebudayaan yang diekspresikan dengan pola perilaku yang berkembang di masyarakat.

Lebih lanjut, Indonesia merupakan negara yang kaya akan kebudayaan. Hal ini dapat dilihat dari banyaknya budaya pada setiap daerah salah satunya di Jawa Timur. Melalui berbagai macam budaya, maka terciptalah suatu kesenian tradisional yang dapat menjadi cri khas pada daerah tersebut. Kesenian Tradisional adalah kesenian masa lalu yang sampai sekarang masih dilakukan dan dimainkan oleh masyarakat kontenporer (Fajrie, 2016). Sedangkan, menurut Prestia dan Susetyo (Hanif, 2018) kesenian tradisional sangat berkaitan dengan kebiasaan dalam penyampaian secara turun temurun yang masih dilakukan oleh masyarakat. Dapat diartikan bahwa kesenian tradisional merupakan kesenian yang tercipta pada masa lampau serta dalam dalam perkembangannya disampaikan secara turun temurun sehingga masih bisa dinikmati oleh masyarakat.

Kesenian tradisional awalnya muncul sebagai hiburan semata, hal ini dikarenakan adanya sisi keindahan dari sebuah kesenian tersebut. Selain itu, kesenian tradisional diciptakan dari hasil olahan karya yang mengandung suatu norma, nilai, pengetahuan maupun kepercayaan yang berasal dari masyarakat yang menciptakan. Kesenian tradisional dalam pewarisannya secara turun temurun menciptakan suatu hal yang menarik sehingga menimbulkan suatu rasa memiliki. Hal tersebut senada dengan pendapat Alwi (Widayati 2012) yang mengungkapkan bahwa kesenian tradisional merupakan kesenian milik bersama yang diciptakan oleh banyak orang serta mengandung unsur keindahan.Hasil dari suatu kesenian tradisional biasa disebut dengan tradisi, yang diberikan dalam bentuk pewarisan budaya dari nenek moyang kepada generasi penerus. Hal tersebut sejalan dengan pendapat Sutiyono (Hanif, 2018) yang mengatakan bahwa seni tradisi merupakan suatu seni yang telah lahir dan hidup sejak lama serta diwariskan secara turun temurun kepada penerusnya. Tradisi sangat erat kaitannya dengan spiritual maupun kepercayaan. Dikarenakan sebuah tradisi dibangun dari rasa kepercayaan masyarakat terhadap sesuatu yang dianggap memiliki nilai yang lebih serta hal tersebut sering dilakukan dalam kehidupan masyarakat. Hal serupa juga dikatakan oleh Sumardjo (Julia, 2018) bahwa tradisi merupakan media 
sakral yang dapat menciptakan daya-daya spriritual. Sedangkan, tradisi sendiri secara umum dapat diartikan sebagai segala sesuatu yang dilakukan berulang kali sehingga menjadi suatu kebiasaan yang dianggap memiliki nilai yang lebih oleh masyarakat. Begitupun dengan makna dari tradisional yang diartikulasikan sebagai cara berfikir maupun berperilaku yang berpedoman pada suatu norma serta adat istiadat yang berlaku dalam masyarakat yang diwariskan secara turun temurun. Kesenian menurut Koentjaraningrat (Hanif, 2018) yaitu suatu konsep dari berbagai ide, norma serta nilai yang berasal dari pola aktivitas manusia itu sendiri yang berwujud seperti benda karya manusia. Jadi, dapat diartikan bahwa kesenian merupakan salah satu kebutuhan manusia untuk mengungkapkan kenikmatan, keindahan bahkan apresiasi terhadap suatu keindahan hasil karya.

Sehingga kesenian tradisional merupakan salah satu bagian dari kebudayaan yang berkembang dari masyarakat serta mengandung norma, nilai maupun pengetahuan yang berlaku di masyarakat itu sendiri sekaligus diwariskan secara turun temurun. Kesenian tradisional kerap dituangkan dalam sebuah hasil karya yang mengandung suatu keindahan. Termasuk dalam wujud sebagai kesenian lokal. Kesenian tersebut merupakan kesenian yang berkembang di masyarakat. biasanya kesenian lokal berkembang dari mulut ke mulut dan diwariskan turun temurun. Kesenian tradisional yang kurang medapatkan dukungan dari masyarakat, perlahan akan mulai surut dan tergantikan dengan kesenian baru. Sehingga kesenian tradisional yang ada harus disesuaikan dengan perkembangan jaman yang ada. (Koentjaraningrat, 1974). Dewasa ini seiring berkembangnya teknologi baru kesenian lokal banyak yang telah dipadukan dengan kesenian-kesenian baru tanpa harus menghilangkan kesenian asli itu sendiri. Akulturasi tersebut memunculkan inovasi baru dalam mengolah sebuah kesenian yaitu salah satunya kesenian tari. Seperti halnya di Madiun, kesenian tradisional juga berkembang berdasarkan kegunaan dan makna nya. Salah satu diantaranya kesenian Gembrungan yang diciptakan untuk memperingati hari besar Islam sekaligus agar masyarakat dapat memahami dan menerapkan nilai-nilai pendidikan, etika, religi, seni, maupun nilai kekeluargaan. (Habsari, 2016).

(Rohidi, Tjetjep Rohendi, 2000) menggolongkan kesenian menjadi empat, yakni seni pertunjukan, seni rupa, seni media rekam, dan seni sastra, sehingga kesenian lokal tidak seharusnya hanya berperan sebagai seni pertunjukan saja. Melainkan dapat dikembangkan dengan melihat dari segi budayanya. Seni pertunjukkan merupakan kesenian dengan mewujudkan ekspresinya melalui pertunjukkan dan yang merupakan seni pertunjukkan antara lain teater, seni musik, seni pencak silat dan seni tari. Jawa Timur terkenal dengan daerah-daerah yang memiliki kesenian lokal yang sangat kental. Salah satunya Kesenian 
Penthul Tembem. Kesenian Penthul Tembemini merupakan salah satu kesenian lokal Kota Madiun. Kesenian Penthul Tembem ditampilkan pada peringatan hari-hari besar, seperti acara bersih desa pada bulan Suro dan peringatan hari kemerdekaan Negara Kesatuan Republik Indonesia. Pada saat pementasan tidak sedikit masyarakat yang menontonnya, namun tidak sedikit masyarakat pula yang mengetahui dan memahami kesenian ini.Kesenian Penthul Tembem masih bisa bertahan hingga kini tentunya tidak lepas dari unsur-unsur pendukung. Pada dasarnya, suatu kesenian masih memiliki suatu kesadaran untuk dilestarikan, artinya kesenian tersebut masih memiliki nilai budaya yang bermakna. Hal tersebut tentunya ada nilai-nilai yang terkandung di dalam Kesenian Penthul Tembemsehingga masyarakat bergerak untuk melestarikan. Namun tidak sedikit masyarakat yang belum mengetahui nilai-nilai budaya yang terkandung di dalam kesenian tersebut. Tujuan penelitian ini adalah menganalisis sejarah dan mendeskripsikan nilai budaya yang terkandung dalam Kesenian Penthul di Kota Madiun. Untuk itu penelitian ini menarik dan perlu dilaksanakan.

\section{Metode}

Peneliti Penelitian mengenai Kesenian Penthul Tembem di Kota Madiun (Studi Sejarah dan Nilai Budaya), dilaksankan di Sanggar Wisma Melati Kota Madiun. Hal ini dikarenakan karena pemilik sanggar Wisma Melati ini salah satu pencipta dari kesnianPenthul Tembem. Penelitian ini dilakukan selama 4 bulan dimulai dari bulan MaretJuni. Berdasarkan penelitian yang diambil yaitu Kesenian Penthul Tembem di Kota Madiun (Studi Sejarah dan Nilai Budaya), maka pendakatan yang dipilih dalam penelitian ini yaitu pendekatan penelitian kualitatif. Pendekatan ini dipilih dikarenakan data yang dihasilkan berupa informasi mengenai sejarah dan nilai budaya kesenian penthul Tembem.

Dalam penelitian ini sumber data yang digunakan yaitu sumber data primer dan sumber data sekunder. Selain itu, penelitian ini menggunakan teknik trianggulasi sumber akagar mendapatkan hasil penelitian yang akurat. Teknik pengumpulan data merupakan langkah utama dalam melakukan sebuah penelitian. Dalam penelitian ini menggunakan metode wawancara, observasi dan dokumentasi.Observasi adalah tenik pengumpulan data yang berupa pengamatan maupun catatan secra sistematis mengenai gejala permasalahan yang dikaji (Firdaus dan Zamzam, 2018). Penelitian ini menggunakan instrumen utama dan bantuan. Finlay (Fitrah dan Luthfiyah, 2017 ) bahwa salah satu karakteristik penelitian kualitatif yaitu peran peneliti sebagai pembentuk pengetahuan, serta pelaksanaan instrumen penelitian. Instrumen utama yaitu peneliti dapat menggunakan logika maupun cara berpikir analitik dalam penelitian ini sehingga dapat menyimpulkan permasalahan yang dikaji. Instrumen bantu yaitu berupa alat-alat yang digunakan untuk mendukung pencarian data 
informasi mengenai penelitian seperti kamera, handphone, tape recorder, alat pencatat. Sehingga dalam tahapan persiapan penelitian sampai dengan penyusunan laporan peneliti menggunakan bantuan alat seperti tape recorder dan camera untuk mempermudah penelitian.Penelitian ini menggunakan teknik analisis data yang bertujuan agar data yang dihasilkan lebih akurat. Menurut Milles dan Huberman (Sugiyono, 2015) bahwa analisis data penelitian kalitatif dilakukan secara terus menerus dengan tahapan Reduksi Data, penyajian data dan penyimpulan.

\section{Hasil Dan Pembahasan}

\section{A. Sejarah Kesenian Penthul Tembem}

Kesenian Penthul Tembem merupakan kesenian asli Kota Madiun. Kesenian ini menjadi aset besar bagi Kota Madiun. Dikarenakan, dalam sejarah kesenian Penthul Tembem sangat memiliki kaitan yang erat dengan tempat-tempat bersejarah yang ada di Kota Madiun. Kesenian Penthul Tembem merupakan satu-satunya kesenian tradisi lisan dari Kota Madiun. Munculnya kesenian ini menjadi daya tarik tersendiri dalam bidang seni di kota Madiun. Hal tersebut dimulai dari adanya Sanggar Wisma Melati yang merupakan salah satu sanggar seni yang bertujuan untuk melestarikan kebudayaan di Kota Madiun. Sanggar yang dimiliki oleh Eyang Dra. Ny. R. Ngt. Sri Wijati Rahardjo ini telah menorehkan prestasi serta menciptakan kesenian Penthul Tembem. Hal ini diawali disaat sanggar Wisma Melati mendapat surat dari Balai Pelestarian Sejarah dan Tradisi Yogyakarta yang menugaskan untuk mengirim kesenian tradisi lisan khas darah masing-masing. Akhinya terpikirkan mengenai kesenian penthul Tembem. Setelah menelusuri sejarah Penthul Tembem, maka disusunlah alur cerita dalam kesenian ini.Sejarah kesenian Penthul Tembem sendiri sangat berhubungan erat dengan sejarah Madiun. Dimulai dari perjalanan Bagus Burhan (Ranggawarsita) yang diutus oleh ayahnya yaitu Tumenggung Yasadipura dari Kraton Surakarta untuk menimba ilmu kenegaraan dan agama di Pondok Pesantren Tegalsari. Pondok pesantren tersebut dipimpin oleh Kyai Kasan Besari.

Pada saat Bagus Burhan mulai masuk dan belajar di pondok, dalam kesehariannya dia salah satu santri yang nakal. Setiap hari dia mengajak santri lain untuk bermain judi, sambung ayam bahkan berkelahi. Sehingga sangat meresahkan warga lingkungan pondok. Kyai Kasan Besari yang mengetahui perilaku Bagus Burhan merasa sangat marah. Sehingga, suatu hari Bagus Burhan diusir dari Pondok. Disaat Bagus Burhan pergi dari pondok, dia diikuti oleh salah satu abdinya yang bernama Onggoleya dengan hanya membawa sebuah pancing dan kepis.Bagus Burhan dan Onggoleya pergi kearah Madiun dan berhenti di daerah Suronatan untuk mencari kerabat Bagus Burhan. Akhirnya di Madiun, Bagus Burhan dan 
Onggoleya berjualan di pasar Madiun. Mereka berdua berjualan seadanya untuk memenuhi kebutuhan sehari-hari. Disuatu hari anak dari Bupati Madiun yang bernama Raden Ajeng Gombak ingin mencari sesuatu di pasar. Sesampainya di pasar, Gombak tertarik dengan cincin Bagus Burhan yang akhirnya cincin tersebut diberikan dengan cuma-cuma oleh Bagus Burhan.Hal tersebut dikarenakan cincin tersebut peninggalan kakek Bagus Burhan yang telah berpesan jika cincin tersebut diinginkan oleh perempuan maka harus diberikan. Pada akhirnya cincin itu dibawa pulang oleh Raden Ajeng Gombak ke kadipaten. Cincin kemudian diserahkan kepada Ayahandanya (Bupati Madiun saat itu, yaitu Rangga Prawiradirdja l). Setelah Kanjeng Bupati melihat cincin tersebut juga kaget dan heran, karena cincin tersebut bukan buatan desa tetapi buatan dari Keraton dan yang memakai pasti para pejabat ataupun kerabat di Keraton Surakarta. (Bupati Madiun juga masih ada keturunan darah dari Keraton Surakarta).Setelah menanyakan darimana putrinya mendapat cincin tersebut, Sang Bupati lalu memerintahkan seorang Opas untuk memanggil penjualnya dengan diantar Raden Ajeng Gombak untuk menunjukkan siapa orang yang menjual cincin tersebut.

Ketika sudah bertemu dengan Bagus Burhan, Sang Opas meminta agar Bagus Burhan ikut bersamanya ke Kabupaten untuk menghadap Sang Bupati. Tentu saja Bagus Burhan sangat kaget, tetapi Onggoleya mengatakan agar Bagus Burhan menghadap Sang Bupati dan dia yang menunggu dagangannya.Sesampai di Kabupaten dan ditanya tentang asal-usulnya, Bagus Burhan mengatakan, bahwa dia adalah salah seorang santri dari Tegalsari, Jetis, Ponorogo yang keberadaannya di Madiun dalam rangka mencari bekal untuk hidup. Ketika ditanya, siapa orang tuanya, akhirnya mengaku, bahwa dia adalah putra Tumenggung Yasadipura, dari Surakarta.Betapa terkejutnya Kanjeng Bupati mendengar hal tersebut, karena ternyata, Tumenggung Yasadipura masih saudara misan dengan Kanjeng Bupati, sehingga Bagus Burhan masih temasuk keponakan Kanjeng Bupati. Waktu ditanyakan tentang cincin yang dijual murah kepada Raden Ajeng Gombak, Bagus Burhan pun menjawab, bahwa itu sesuai dengan pesan eyangnya, apabila dikehendaki oleh seorang wanita harus diberikan.

Kanjeng Bupati tanggap akan kata-kata Bagus Burhan, kemudian mengatakan, bahwa itu sudah menjadi kehendak Yang Maha Kuasa, harus terjadi. Ketika ditawarkan, apakah Bagus Burhan mau ikut ke Solo, karena tujuh hari lagi Kanjeng Bupati akan ke Solo untuk mengikuti konferensi, Bagus Burhan menolak, dengan alasan masih harus melaksanakan tugas guna mencapai tujuannya, maka Bagus Burhan lalu mohon pamit untuk kembali ke Pasar. Setelah kembali ke pasar Bagus Burhan mengajak Onggoleya agar pergi dari pasar untuk menjaga nama Bupati. Mereka berdua berjalan menuju arah Caruban. Untuk menyambung hidup mereka berdua memancing dan menjual hasil pancingannya.Sedangkan, 
di pondok Tegalsari setelah sepeninggalan Bagus Burhan keadaan desa mengalami kekacauan. Munculnya wabah penyakit, tidak berkokoknya ayam pada pagi hari serta banyak orang yang pagi hari sakit dan sorenya meninggal. Hal tersebut membuat santri-santri pulang ke daerahnya masing-masing. Kyai Kasan Besari melihat peristiwa itu sangat prihatindan beliau sadar telah melakukan kelalaian. Beliau sadar seharusnya jika sudah tidak menginginkan Bagus Burhan bukan mengusirnya akan tetapi mengembalikan Bagus Burhan kepada ayahnya. Pada akhirnya Kyai Kasan Besari mengutus abdinya yang bernama Kromoleya untuk mencari Bagus Burhan.Kromoleya pergi menuju arah utara sampai ke Madiun. Untuk mencari bekal Kromoleya membuat topeng untuk ngamen di Alun-Alun Madiun. Topeng tersebut berwarna hitam yang dinamakan Tembem. Ketika Bagus Burhan dan Onggoleya sedang lewat di Alun-Alun Madiun mereka singgah di Masjid untuk melaksanakan solat. Sementara Bagus Burhan di dalam masjid dan Onggoleya di luar masjid yang mendengar dan melihat ada keramaian di Alun-Alun. Akhirnya Onggoleya menghampiri dan ikut menari dengan menggunakan topeng berwarna putih yang bernama Penthul.

Setelah Kromoleya mengetahui, bahwa yang menemani menari itu tiada lain temannya sendiri Onggoleya, maka sambil terus menari, mereka saling bertanya tentang keadaan masing-masing dan Kromoleya menanyakan tentang keberadaan Bagus Burhan. Onggoleya menjawab agar tetap menari saja, sedang tentang Bagus Burhan tidak perlu ditanyakan dulu. Setelah selesai, Kromoleya bertanya kembali tentang keberadaan Bagus Burhan, lalu dijawabnya, bahwa Bagus Burhan sedang berada di Mesjid. Onggoleya kemudian mengajak Kromoleya menjemput dimana untuk selanjutnya akan diantar pulang ke Tegalsari. Akhirnya Bagus Burhan pulang ke Tegalsari dan menghadap Kyai Kasan Besari. Untuk menebus kesalahannya Bagus Burhan bersedia untuk menerima hukuman. Bagus Burhan dan Onggoleya harus berpuasa selama 40 hari. Dalam puasanya Bagus Burhan hanya boleh berbuka satu buah pisang. Mereka berdua tidak makan dan tidak tidur diatas sebuah sungai selama 40 hari.

Hal tersebut dilakukan dengan cara sebatang bambu dibentangkan diatas sungai, kemudian mereka berdua (Bagus Burhan dan Onggoleya) duduk diatas bambu tersebut sampai semalam suntuk. Jika, mereka mengantuk, maka mereka akan jatuh kesungai yang dalam dan airnya mengalir dengan deras. Jadi bila sampai terjatuh maka sudah pasti akan basah kuyup. Genaplah 40 hari puasa mereka. Pada hari terakhir Bagus Burhan berkata kepada Onggoleya agar menanak nasi untuk persiapan makan pagi keesokan harinya. Pada kira-kira jam dua dini hari, Onggoleya menanak nasi disebuah kendhil (periuk). Ketika selesai menanak nasi, ada sinar dari arah Barat seperti ndaru (pulung) masuk kedalam 
periuk, baunya sangat harum. Sekitar jam empat pagi, Bagus Burhan berkata kepada Onggoleya, agar nasi diangkat dari periuk. Berdua mereka kemudian mendekati periuk.Waktu kendhil (periuk) dibuka, ternyata didalamnya ada seekor ikan Badher yang baunya sedap dan harum sekali. Bagus Burhan kemudian makan badannya dan Onggoleya kepalanya. Berdua mereka makan sampai kenyang. Menjelang jam setengah lima pagi, terdengar suara kentongan dan diikuti suara bedhug dari Masjid, sebagai tanda bahwa saat Subuh telah tiba, keduanya lalu pergi ke Masjid untuk menunaikan sholat Subuh.Setelah kurang lebih dua tahun berada dipesantren Tegalsari, Bagus Burhan diantarkan kembali ke Surakarta. Adapun yang mengantarkan adalah Kyai Ageng Kasan Besari beserta Onggoleya dan Kromoleya. Sesampainya di Surakarta langsung diserahkan kepadaTumenggung Yasadipura.Kedatangan Kyai Ageng Kasan Besari di Surakarta, membuat Tumenggung Yasadipura senang sekali hatinya. Karena sangat senangnya kemudian beliau mengadakan acara Tayuban. Kyai Ageng Kasan Besari dipersilakan menari tidak mau, kemudian diwakili oleh Kromoleya. Ketika Kromoleya menari banyak orang yang senang dan tertawa, karena tariannya lemah gemulai serta lucu sekali. Kyai Ageng Kasan Besari berada di Surakarta lebih kurang tiga hari, kemudian kembali ke Tegalsari.

Tidak berapa lama, sepulangnya Kyai Ageng Kasan Besari dari Surakarta, Kanjeng Bupati Madiun beserta Raden Ajeng Gombak datang ke Surakarta lalu Bagus Burhan dinikahkan dengan Raden Ajeng Gombak. Selanjutnya Bagus Burhan diabdikan kepada Ingkang Sinuhun. Akhimya Bagus Burhan menjadi orang kepercayaan Ingkang Sinuhun di Surakarta, dalam mengendalikan pemerintahan, yang mendapat kepercayaan untuk menyelesaikan segala persoalan yang timbul didalam maupun diluar Keraton. Bagus Burhan dijadikan Pujangga Keraton oleh Sinuhun dengan sebutan Raden Ngabehi Ranggawarsita, yang namanya harum keseluruh tanah air. Proses bertemunya Kromoleya dan Onggoleya di Alun-alun Madiun dengan menggunakan topeng itulah yang disebut dengan KesnianPenthul Tembem. Dari cerita itulah disusun naskah yang biasanya dipakai untuk melakukan pertunjukan. Namun, cerita yang mengandung sejarah besar ini kurang diketahui oleh masyarakat dan perlu adanya upaya untuk melestarikan kesenian Penthul Tembem ini. 


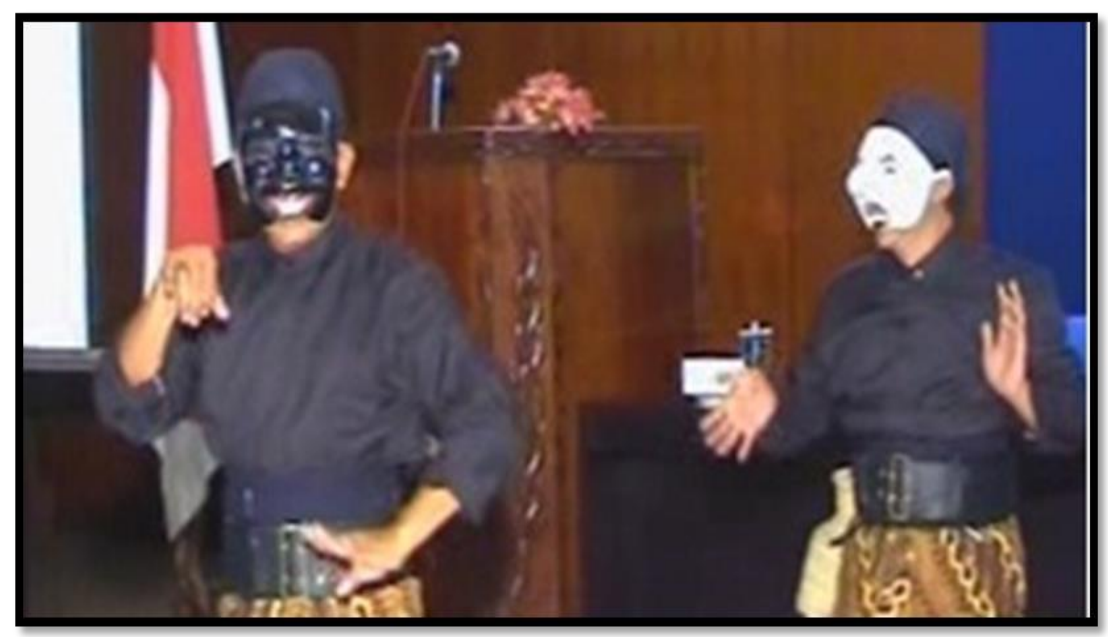

\section{Gambar 1. Pementasan Kesenian Penthul Tembemdi Kabupaten Madiun (Dokumentasi Sanggar Wisma Melati, 2006)}

Kesenian Penthul Tembem pernah mengalami perkembangan pada tahun 2006 setelah kesenian ini mengikuti festival Kesenian Tradisional yang diselenggarakan di Balai Kesenian Yogyakarta yang mewakili Jawa Timur. Selain festival kesenian ini juga diikutkan dalam lomba kesenian tradisi lisan, mengisi kegiatan-kegiatan warga seperti bersih desa, serta ditampilkan dalam acara kenegaraan di Balai Kota Madiun. Pada tahun tersebut masih didukung dengan adanya pemain serta masih adanya dukungan dari pemerintah daerah. Akan tetapi lambat laun kesenian ini mulai hilang kembali sejak para pemain penthul Tembem sudah berada di usia tua. Sayangnya, tidak ada pelaku seni muda yang tertarik untuk mempelajari kesenian ini.Selanjutnya pada tahun 2016, kesenian Penthul Tembem ini dikembangkan oleh salah satu komunitas penggiat seni yang bernama KIM Citra Winongo. Dalam pengembangannya kesenian penthul Tembem dapat divariasikan untuk penampilan dalam karnaval maupun tarian. Namun, dalam tariannya tidak ada pakem tertentu yang mewajibkan mengenai gerakan maupun musiknya. Hal tersebut juga sesuai dengan kesenian tradisi lisannya yang tidak memiliki pakem tertentu dalam penmpilannya. Kesenian ini hanya menyajikan sebuah narasi seperti ketoprak yang didalam alur ceritanya disisipi mengenai informasi-informasi terbaru. Setelah adanya pengembangan kesenian ini mulai kembali terangkat. Hal tersebut dibuktikan dengan ditampilkannya kesenian ini dalam acara warga seperti bersih desa Winongo, kegiatan Pertura III Kecamatan Manguharjo, diundangnya dalam resepsi kenegaraan di Balai Kota Madiun. 


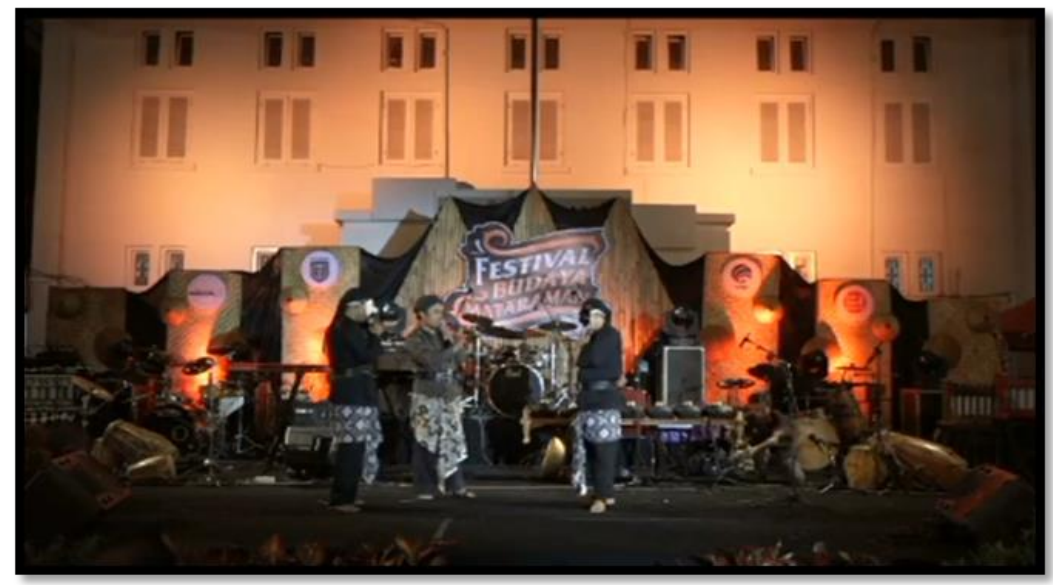

\section{Gambar 2. Penampilan Kesenian Penthul Tembemdi Festival Mataraman di Balai Kota Madiun} (Dokumentasi Pribadi, 2018)

Selain itu, kesenian Penthul Tembem juga ditampilkan dalam festival Mataraman yang diadakan oleh Pemerintah Kota Madiun di Balai Kota Madiun pada tanggal 9 November 2018.Namun kesenian Penthul Tembem ini kurang diminati oleh masyarakat dan para pemuda Kota Madiun. Sehingga membuat pelaku seni penthul Tembem menjadi berkurang. Selain itu kesenian penthul Tembem pada saat ini kurang juga diminati. Serta belum adanya tanggapan atau tindakan lanjut dari pemerintah Kota Madiun. kesenian penthul Tembem saat ini masih hanya dijadikan sebagai aset kebudayaan Kota Madiun namun belum menjadi icon Kota Madiun.

\section{B. Nilai Budaya dalam Kesenian Penthul Tembem.}

Kesenian Penthul Tembem sebagai sebuah karya, cipta dan rasa tentunya memiliki nilai budaya. Nilai budaya sendiri dapat diartikan bahwa sesuatu yang dianggap sangat berharga dalam sebuah seni. Dalam hal ini nilai budaya berperan penting pada kehidupan bermasyarakat seperti yang dikatakan Soekanto dan Sulistyowati (Hanif, 2016) yang mengungkapkan bahwa fungsi dari nilai budaya yaitu sebagai bekal dalam menghadapi permasalah di masyarakat agar manusia dapat mengerti bagaimana harus bersikap maupun bertindak tanpa menimbulkan suatu kesalahpahaman dan perpecahan antar masyarakat. Kesenian Penthul Tembempertama kali ditampilkan oleh Sanggar Kesenian Wisma Melati dalam festival budaya tradisi lisan di Yogyakarta. Perpaduan musik, tata busana serta alur cerita yang bervariasi dapat menciptakan estetika tersendiri. Kesenian Penthul Tembem ini juga di variasikan kembali oleh KIM Citra Kenanga ke dalam bentuk seni tari. Hal tersebut dapat mempeluas jangkauan masyarakat dalam mempelajari Kesenian Penthul Tembem. 
Budaya merupakan identitas dari adanya peradaban yang merupakan ciri khas antara daerah satu dengan yang lain. Dalam konteks lain, kebudayaan terbentuk melalui proses konsepsi dari pemahaman untuk menerapkan logika dan bahasa secara potensial dalam jiwa manusia. (Edi Sdyawati, 2014). Nilai Budaya kesenian Penthul Tembem ini tidak hanya sekedar tulisan, akan tetapi nilai budaya ini benar-benar diaplikasikan dalam kehidupan bermasyarakat khususnya dalam pendidikan. Sementara menurut (Ida, 2015)nilai budaya merupakan nilai yang diyakini baik oleh masyarakat setempat dan dapat dijadikan pedoman bagi kelompok atau masyarakat tertentu. Dapat dilihat dari penerapan SMK YP 17 Kota Madiun yang telah menerapkan nilai budaya kesenian Penthul Tembem. Penerapan kesenian Penthul Tembem sebagai ekstrakurikuler menjadi pilihan yang tepat untuk memperkenalkan kepada generasi muda. Dengan tindakan tersebut maka para siswa dengan mudah untuk memahami dan mengetahui Kesenian Penthul Tembem terkhususnya.

Banyak sekali nilai budaya yang terkandung dalam kesenian penthul Tembem ini dan semuanya dapat berguna dalam kehidupan bermasyarakat. Di berbagai tempat memiliki sebuah nilai-nilai tersendiri yang tergantung dengan tradisi yang ada di tempat mereka. Nilai banyak terdapat dalam berbagai hal terutama dalam kehidupan bermasyarakat yang berbudaya serta menjunjung tinggi nilai-nilai tertentu. Nilai budaya yang terkandung dalam kesenian Penthul Tembem tidak hanya tersirat saja pada cerita dramanya, akan tetapi juga terdapat pada sejarah kesnian tersebut. Nilai-nilai budaya dari Kesenian Penthul Tembem dapat diuraikan sebagai berikut:

1. Nilai Moral

Dalam kesenian Penthul Tembem tersisipkan nilai moral yang digambarkan dari cerita latar belakang kesenian yaitu disaat Bagus Burhan tetap kukuh untuk menyelesaikan tanggung jawab yang diberikan ayahnya dalam belajar agama dan ketatanegaraan di Tegalsari dan menolak ajakan Bupati Madiun untuk kembali ke Surakarta. Selain itu, dapat dilihat disaat Bagus Burhan setelah kembali ke Tegalsari dengan kerja keras dan tekun menjalani puasa selama 40 hari yang dianjurkan oleh Kyai Kasan Besari untuk menebus kesalahannya. Dalam sejarah Kesenian Penthul Tembem ini mengajarkan untuk selalu menjadi manusia yang bertanggung jawab terhadap apapun serta bekerja keras untuk mendapatkan hal yang diinginkan. Nilai moral bermanfaat jika dijadikan pedoman dalam berkehidupan di masyarakat. Apalagi jika dapat disisipkan dalam pendidikan karakter di lingkungan sekolah khususnya Kota Madiun. 
2. Nilai Religi

Nilai religi merupakan sesuatu yang berkitan dengan agama dan kepercayaan. Dilihat dari cerita sejarahnya Kesenian Penthul Tembem mengandung nilai-nilai keagamaan bahwa apapun yang dilakukan manusia di dunia haruslah berpedoman pada agama yang dianut. Disisi lain sebagai manusia yang memiliki agama maka hukumnya wajib untuk belajar dan meyakini agamanya.Seperti yang digambarkan dalam cerita Penthul Tembem ini dimana Tumenggung Yosodipura yang memberikan tugas kepada anaknya untuk belajar ilmu agama bagi kehidupannya.

3. Nilai Kepemimpinan

Kesenian Penthul Tembem mengandung nilai kepemimpinan sebagaimana dapat dilihat dari sikap Kyai Kasan Besari yang tidak malumengakui kesalahannya karena sudah mengusir Bagus Burhan dari pesantren dimana seharusnya jika Bagus Burhan melakukan kesalahan maka harus dipulangkan ke ayahnya. Karena rasa tanggung jawabnya kepada Tumenggung Yosodipura, maka Kyai Kasan Besari mengutus Kromoleya untuk mencari Bagus Burhan agar kembali ke Tegalsari. Hal ini menggambarkan bahwa sosok Kyai Kasan Besari memiliki watak yang bertanggung jawab dan bijaksana. Hal ini dapat dijadikan sebagai contoh maupun suri tauladan masyarakat dalam menjalankan sebuah kehidupan bermasyarakat.

4. Nilai Estetika

Dilihat dari berbagai aspek kesenian Penthul Tembem merupakan sebuah kesenian yang memiliki nilai estetika yang tinggi dimana adanya perpaduan antara Islam dengan Jawa. Kesenian Penthul Tembem ini mengandung nilai estetika yang ditunjukkan dari perpaduan tata rias, tata busana serta musik yang disajikan dengan alur atau naskah cerita yang indah. Namun, tidak menhilangkan cerita aslinya yaitu kisah dari Bagus Burhan dalam menuntut ilmu agama dan ketatanegaraan di Tegalsari.

5. Nilai Hiburan

Kesenian Penthul Tembem adalah kesenian tradisi lisan dimana di dalam penyajiannya dapat disisipkan sebuah informasi. Kesenian ini mengandung nilai pendidikan karena di setiap naskah atau alur ceritanya dapat dikreasikan dengan informasi-informasi yang bermanfaat sesuai dengan jamannya. Dalam hal ini, kesenian Penthul Tembem dapat dijadikan sarana memperluas wawasan. Jadi, selain berasal dari sekolah informasi-informasi dapat berasal dari variasi kesenian yang ada. Selain itu, kesenian ini dapat dimodifikasi dengan berbagai cerita yang dapat memunculkan kesan yang menarik serta sebagai hiburan bagi para penikmatnya. 


\section{Kesimpulan}

Kesenian Penthul Tembemini tidak memiliki pakem tertentu dalam pementasan maupun alur ceritanya. Jadi, dalam alur ceritanya dapat dikreasikan serta disisipi informasiinformasi lainnya. Adapun nilai budaya yang terkandung dalam kesenian Penthul Tembem dapat dilihat dari cerita sejarahnya serta dari pementasan kesenian itu sendiri. Nilai budaya yang terkandung dalam kesenian penthul Tembem yaitu nilai moral, nilai kepemimpinan, nilai kerohanian/agama, nilai estetika, dan nilai hiburan. Nilai-nilai tersebut dapat ditrapkan di masyarakat dalam mengatasi permasalahan masyaraat. Selain itu, nilai budaya ini cocok jika diterapkan di kalangan pelajar. Implikasi penelitian ini adalah mengembangkan kesenian ini agar lebih dikenal banyak orang, serta perlu dilakukan penelitian dan peninjauan kembali supaya segera ditindaklanjuti dalam upaya pelestariannya.

\section{Daftar Pustaka}

Edi Sdawati. (2014). Kebudayaan Indonesia. Depok: Komunitas Bambu.

Firdaus \& Zamzam, F.(2018). Aplikasi Metodologi Penelitian.Yogyakarta: Deepublish Fajrie, Mahfudlah. (2016). BUDAYA MASYARAKAT PESISIR WEDUG JAWA TENGAH (Melihat Gaya Komunikasi dan Tradisi Pesisiran). Wonosobo: CV. Mangku bumi Media.

Habsari, N.T dan Roda'i, R. K. (2016). Kesenian Gembrungan di Desa Kaibon, Kecamatan Geger, Kabupaten Madiun( Kajian Nilai-Nilai Kearifan Lokal sebagai Pembelajaran Sejarah Lokal. Jurnal Agastya, 6(2), 112-136.

Hanif, Muhammad. (2018). Kesenian Dongkrek ( Studi Nilai Budaya dan Potensinya sebagai Sumber Pendidikan Karakter: Gulawentah Jurnal studi Sosial, 1(2). 132-141.

Ida Agustina Puspita Sari. (2015). Mitos Dalam ajran Turonggo Yakso di Kecamatan Dongko Kabupaten Trenggalek. Karya tulis berupa skripsi.

Julia. (2018). Kapita Selekta Seni, Budaya, dan Pendidikan. Sumedang: UPI Sumedang Press.

Koetjaraningrat. (1974). Kebudayaan, Mentalitet dan Pembangunan. Jakarta: Penerbit Gramedia.

Kottak, C. P. (1991). Anthropologi: The Exploration of Human Diversity, 5th Edition. New York: Mc Graw-Hill Inc

Luthfiyah \& Fitrah, M. (2017). Metodologi Penelitian: Penelitian Kualitatif, Tindakan Kelas \& Studi Kasus. Sukabumi: Jejak

Pemerintah Kota Madiun. (2019). Analisis Strategis Smart City Kota Madiun 2019-2020. Madiun

Rohidi, Tjetjep Rohendi. (2000). Kesenian dalam Pendekatan Kebudayaan. Bandung. Accent Graphic Communication

Sulistyo, E.T. (2005). Kaji Dini Pendidikan Seni. Surakarta: UNS Press.

Sugiyono. (2015). Metode Penelitian Kuantitatif, Kualitatif dan R\&D. Bandung: Alfabeta

Widayati, Asri. (2012). Fungsi Kesenian Ledhek Dalam Upacara Bersih Desa Di Dusun Karangtengah, Desa Ngalang, Gedangsari, Gunungkidul. Skripsi tidak diterbitkan. Yogyakarta: Jurusan Pendidikan seni Tari 